\title{
Neuroprotective Principles from Gastrodia elata
}

\author{
Nai-Kuei Huang, ${ }^{\dagger}$ Yijuang Chern,${ }^{\ddagger}$ Jim-Min Fang,${ }^{\S}$ Chia-I Lin, ${ }^{\S}$ Wan-Ping Chen, ${ }^{\dagger}$ and Yun-Lian Lin* ${ }^{\dagger}$ \\ National Research Institute of Chinese Medicine, Taipei 112, Taiwan, Republic of China, Institute of Biomedical Sciences, Academia Sinica, \\ Nankang, Taipei 115, Taiwan, Republic of China, and Department of Chemistry, National Taiwan University, Taipei 106, Taiwan, \\ Republic of China
}

Received October 19, 2006

\begin{abstract}
Serum deprivation-induced neuronal-like PC12 cell apoptosis was used as an ischemic/hypoxic model to screen neuroprotective compounds from the rhizomes of Gastrodia elata, a traditional Chinese medicine. Two active compounds, bis(4-hydroxybenzyl)sulfide (1) and $N^{6}$-(4-hydroxybenzyl)adenine riboside (2), together with 15 known compounds were obtained from the active fraction. Compound $\mathbf{2}$ was further elucidated by chemical synthesis. Compounds $\mathbf{1}$ and 2 potently prevented PC12 cell apoptosis in concentration-dependent manners with $\mathrm{EC}_{50}$ values of $7.20 \mu \mathrm{M}$ and $3.7 \times$ $10^{-8} \mathrm{M}$, respectively, and $\mathrm{IC}_{50}$ values of $42.90 \mu \mathrm{M}\left(K_{\mathrm{i}} 24.10 \mu \mathrm{M}\right)$ and $4.660 \mu \mathrm{M}\left(K_{\mathrm{i}} 2.620 \mu \mathrm{M}\right)$, respectively, in an adenosine $\mathrm{A}_{2 \mathrm{~A}}$ receptor binding assay.
\end{abstract}

Neuronal cell death induced by apoptosis is a normal aspect of development in which the death program is triggered by failure of a given neuron to receive limited supplies of target-derived neurotrophic factors. Apoptosis can be triggered in a rat phechromocytoma (PC12) cell culture system by deprivation of either serum $^{1}$ or trophic factor/nerve growth factor, ${ }^{2}$ and thus these are commonly used to study neuronal differentiation and cell death. In Huntington's disease, GABAergic striopallidal neurons selectively degenerate in sync with the progression of the disease. ${ }^{3}$ Mutant huntingtin is known to bind to transcriptional factors and as a consequence to reduce acetylated histone levels, which causes reduced expressions of genes essential for neuronal survival. ${ }^{4}$ In the brain, the adenosine $A_{2 A}$ receptor $\left(A_{2 A}-R\right)$ gene is heavily expressed in GABAergic striopallidal neurons. ${ }^{3}$ During neuronal development, expression of $\mathrm{A}_{2 \mathrm{~A}}-\mathrm{R}$ is transiently regulated in various areas of the developing rat brain, ${ }^{5}$ suggesting that adenosine may play an important role in brain development. ${ }^{6}$ Additionally, an $\mathrm{A}_{2 \mathrm{~A}^{-}}$ $\mathrm{R}$-specific agonist was shown to specifically ameliorate several major symptoms of neural degenerative disease. ${ }^{7}$

The rhizomes of Gastrodia elata have been used in traditional Chinese medicine for the treatment of headaches, dizziness, vertigo, and convulsive illnesses, such as epilepsy and tetanus. ${ }^{8}$ In line with these medicinal uses, many studies have been performed to evaluate the effects of $G$. elata on the prevention of neuronal damage, ${ }^{9-15}$ which have been supplemented by a series of phytochemical studies. ${ }^{16-23}$ Additionally, we previously reported that an aqueous ethanolic extract of G. elata exhibited activity in preventing PC12 cell apoptosis induced by serum deprivation through suppression of the JNK pathway. ${ }^{15}$ In a continuation of this investigation, we herein report the isolation of two active compounds, bis(4hydroxybenzyl)sulfide (1) and $N^{6}$-(4-hydroxybenzyl)adenine riboside (2), which demonstrated the ability to prevent serum deprivationinduced apoptosis in PC12 cells and to bind $\mathrm{A}_{2 \mathrm{~A}}-\mathrm{R}$. Notably, compound $\mathbf{2}$ was first found from a natural source, and its structure was verified through synthesis.

\section{Results and Discussion}

An aqueous ethanolic extract of $G$. elata was first concentrated in vacuo and then fractionated using a Diaion HP-20 column with an elution gradient from $\mathrm{H}_{2} \mathrm{O}$ to $\mathrm{MeOH}$. Fractions showing protection of PC12 cells from serum deprivation-induced apoptosis

* Corresponding author. Tel: +886-2-28201999, ext. 6531. Fax: +8862-28250743. E-mail: yllin@nricm.edu.tw.

$\pitchfork$ National Research Institute of Chinese Medicine.

Institute of Biomedical Sciences, Academia Sinica.

$\S$ Department of Chemistry, National Taiwan University.

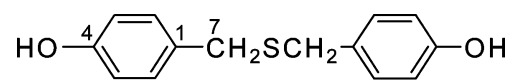

1

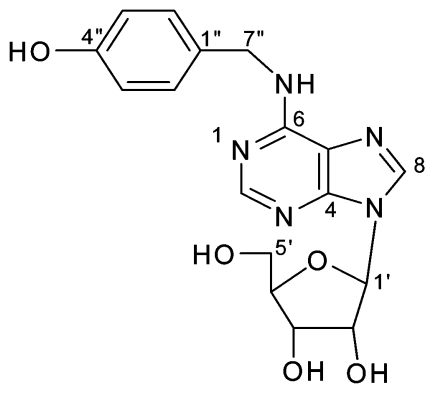

2

were then subjected to further chromatography using Sephadex LH20 and RP-18 columns. Among 17 purified compounds, bis(4hydroxybenzyl) sulfide $(\mathbf{1})^{22}$ and $N^{6}$-(4-hydroxybenzyl)adenine riboside (2) were identified as the active components in the PC12 assay system. The remaining compounds were 4-hydroxybenzaldehyde, ${ }^{16}$ 4-hydroxybenzyl alcohol, ${ }^{16}$ 4-hydroxybenzyl methyl ether, ${ }^{16}$ 4-hydroxybenzyl ethyl ether, ${ }^{23}$ 1,4-benzenediol, ${ }^{24}$ gastrodin, ${ }^{16} 4$-( $\beta$-D-glucopyranosyloxy)benzyl methyl ether, ${ }^{16}$ parishin, ${ }^{16}$ bis(4-hydroxybenzyl) ether, ${ }^{17}$ trimethyl citrate, ${ }^{25}$ bis(4-hydroxybenzyl) sulfoxide, ${ }^{20}$ bis(4-hydroxybenzyl), ${ }^{19}$ 5-(hydroxymethyl)-2furfuraldehyde, ${ }^{26}$ uridine,${ }^{27}$ and adenosine.$^{27}$ The structures of the aforementioned compounds were elucidated via their 1D and 2D NMR and MS analyses and by comparisons with published data. Of the 15 compounds, trimethyl citrate was likely an artifact.

Compound 2 was isolated as colorless needles with an mp of 216-219 ${ }^{\circ} \mathrm{C}$. Its molecular formula of $\mathrm{C}_{17} \mathrm{H}_{20} \mathrm{O}_{5} \mathrm{~N}_{5}$ was deduced from the HRFABMS ion at $\mathrm{m} / z$ 374.1361 $[\mathrm{M}+\mathrm{H}]^{+}$and the ${ }^{13} \mathrm{C}$ NMR data. The IR spectrum suggested the presence of hydroxy (3327, 1125, and 1057, $\mathrm{cm}^{-1}$ ) and aromatic moieties (1630 and $\left.1514 \mathrm{~cm}^{-1}\right)$. The ${ }^{1} \mathrm{H}$ and ${ }^{13} \mathrm{C}$ NMR spectra showed a pattern similar to those of adenosine $\left[\delta_{\mathrm{H}} 3.57\right.$ and $3.64(1 \mathrm{H}$ each, $\mathrm{m}), 3.95(1 \mathrm{H}, \mathrm{t}$, $J=1.8 \mathrm{~Hz}), 4.13(1 \mathrm{H}, \mathrm{m}), 4.60(1 \mathrm{H}, \mathrm{m}), 5.88(1 \mathrm{H}, \mathrm{d}, J=5.5 \mathrm{~Hz})$ 8.20 and 8.35 (1H each, s), 8.28 and 9.19 (1H each, br s); $\delta_{\mathrm{C}} 61.7$ (t), 70.7 (d), 73.5 (d), 85.9 (d), 88.0(d), 120.4 (s), 139.8 (d), 148.4 (s), $152.3(\mathrm{~d})$, and 154.4 (s)] except for a $p$-hydroxybenzylamine moiety $\left[\delta_{\mathrm{H}} 4.60(2 \mathrm{H}, \mathrm{m}, J=6.0 \mathrm{~Hz}), 6.66\right.$ and $7.14(2 \mathrm{H}$ each, $\mathrm{d}$, $J=8.5 \mathrm{~Hz}) ; \delta_{\mathrm{C}} 42.4(\mathrm{t}), 114.9(\mathrm{~d}), 114.9$ (d), 128.6 (d), 128.6 (d), 130.8 (s, C-1"), and 156.1 (s, C-4")] in compound 2, 
Scheme 1. Semisynthesis of Compound 2<smiles>O=Cc1ccc(O)cc1</smiles><smiles>COC(=O)NOC(=O)O</smiles>

rt, 6 h; $70 \%$

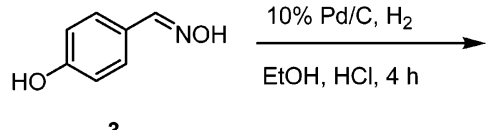

3

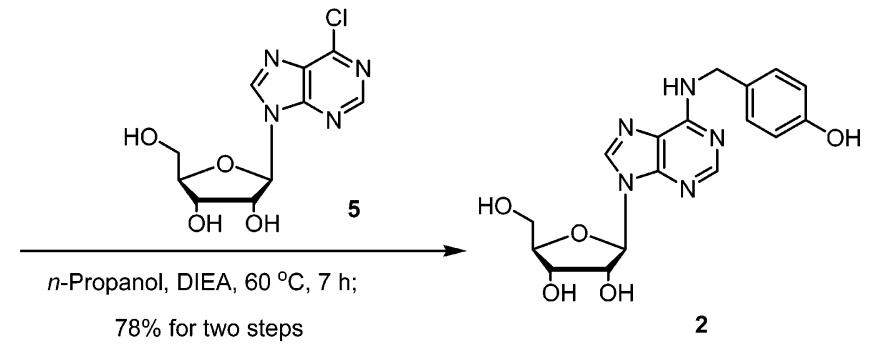

substituting the amino group in adenosine. The linkage of the p-hydroxybenzylamino group to $\mathrm{C}-7$ was supported by $\mathrm{HMBC}$ correlations of $\mathrm{H}-7^{\prime \prime}$ with $\mathrm{C}-1^{\prime \prime}, \mathrm{C}-2^{\prime \prime}\left(6^{\prime \prime}\right)$, and C-6 and by comparison of the ${ }^{1} \mathrm{H}$ and ${ }^{13} \mathrm{C}$ NMR data with those of $N^{6}-(m-$ hydroxybenzyl)adenine, a plant growth regulator that was reported by Strnad et al. ${ }^{28}$ The $m$-hydroxybenzyl group was replaced by a $p$-hydroxybenzyl in $\mathbf{2}$. This is the first report of the presence of compound $\mathbf{2}$ in a natural source. Its structure was further confirmed by semisynthesis via the substitution reaction of 4-hydroxybenzylamine hydrochloric salt (4) and 6-chloropurine ribonucleoside (5) in the presence of diisopropylethylamine (Scheme 1). The synthetic sample of compound 2 showed identical MS and ${ }^{1} \mathrm{H}$ and ${ }^{13} \mathrm{C}$ NMR spectroscopic profiles to those of the natural product.

All of the aforementioned compounds were subjected to the protection assay for the prevention of PC12 cell apoptosis induced by serum deprivation. Both compounds $\mathbf{1}$ and $\mathbf{2}$ showed significant efficacy in a concentration-dependent manner (Figure 1A), with $\mathrm{EC}_{50}$ values of $7.20 \pm 0.20 \mu \mathrm{M}$ and $(3.7 \pm 0.3) \times 10^{-8} \mathrm{M}$, respectively. In the $\mathrm{A}_{2 \mathrm{~A}}$ receptor binding assay compound $\mathbf{1}$ had an $\mathrm{IC}_{50}$ of $42.90 \pm 3.35 \mu \mathrm{M}$ and a $K_{\mathrm{i}}$ value of $24.10 \pm 1.88 \mu \mathrm{M}$, whereas those for compound 2 were $4.660 \pm 0.051 \mu \mathrm{M}$ and 2.620 $\pm 0.029 \mu \mathrm{M}$, respectively. However, the major components, parishin and gastrodin, showed no protective effect even at a concentration higher than $1 \times 10^{-4} \mathrm{M}$, whereas the protective effect of adenosine was about $80 \%$ at $1 \times 10^{-4} \mathrm{M}$ (Figure $1 \mathrm{~B}$ ). In this study, the $\mathrm{A}_{2 \mathrm{~A}} \mathrm{R}$ activity level of compound $\mathbf{2}$ was similar to those reported for $\mathrm{N}^{6}$ substituted adenosines (such as $N^{6}$-phenyladenosine) and $\mathrm{N}^{6}$ substituted 2-chloroadenosines for rat brain striatum $\mathrm{A}_{2}$ adenosine receptor $\left(\mathrm{A}_{2 \mathrm{~A}} \mathrm{R}\right){ }^{29}$

In summary, two neuroprotive compounds (1 and $\mathbf{2})$ were isolated from the active fraction of G. elata. Compound $\mathbf{2}$ has not previously been reported from natural sources. Both $\mathbf{1}$ and $\mathbf{2}$ prevent serumdeprived PC12 cell apoptosis, suggesting a therapeutic potential in treating neurotoxicity or as neuroprotectants and are candidates for further development in the therapeutic use against neural degenerative disease.

\section{Experimental Section}

General Experimental Procedures. Melting points were determined on a Yanagimoto micromelting point apparatus and are uncorrected. IR spectra were recorded on a Nicolet Avatar 320 FT-IR spectrophotometer. UV spectra were measured on a Hitachi U-3310 spectrophotometer. NMR spectra were run on Varian unity INOVA-500 and Bruker AVANCE 400 spectrometers. Mass spectra (EIMS, HREIMS, and HRFABMS) were recorded on a JEOL JMS-100 and a JEOL SX$102 \mathrm{~A}$ instrument, respectively.

Plant Material. Dried rhizomes of G. elata (GE) (12 kg) were purchased from a local herbal store in Taipei. The specimen was identified by comparison with voucher specimens deposited earlier at the Herbarium of National Research Institute of Chinese Medicine.
Extraction and Isolation. Slices of GE were extracted at $60{ }^{\circ} \mathrm{C}$ using $80 \%$ EtOH overnight $(3 \times 60 \mathrm{~L})$. The crude extract was concentrated under reduced pressure. The dried sample (which had

(A)

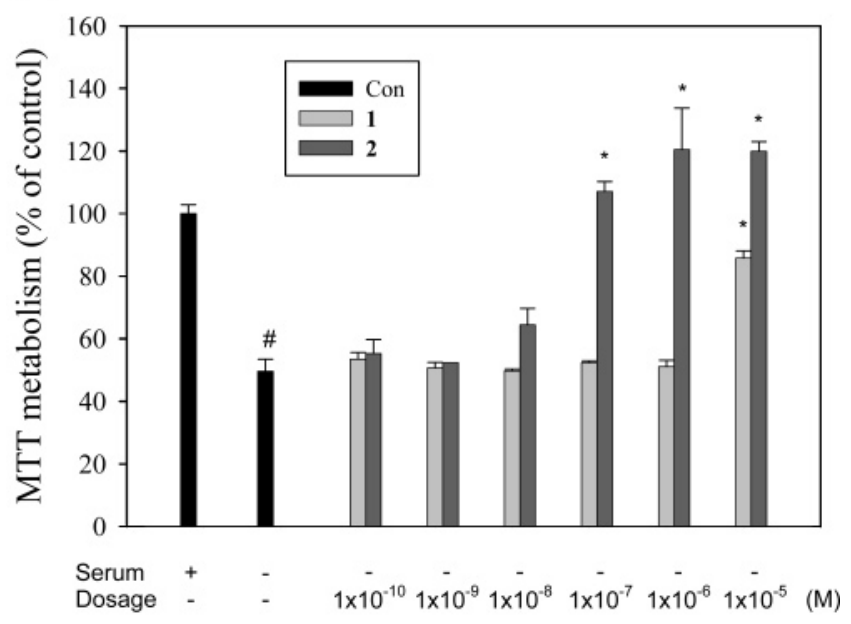

(B)

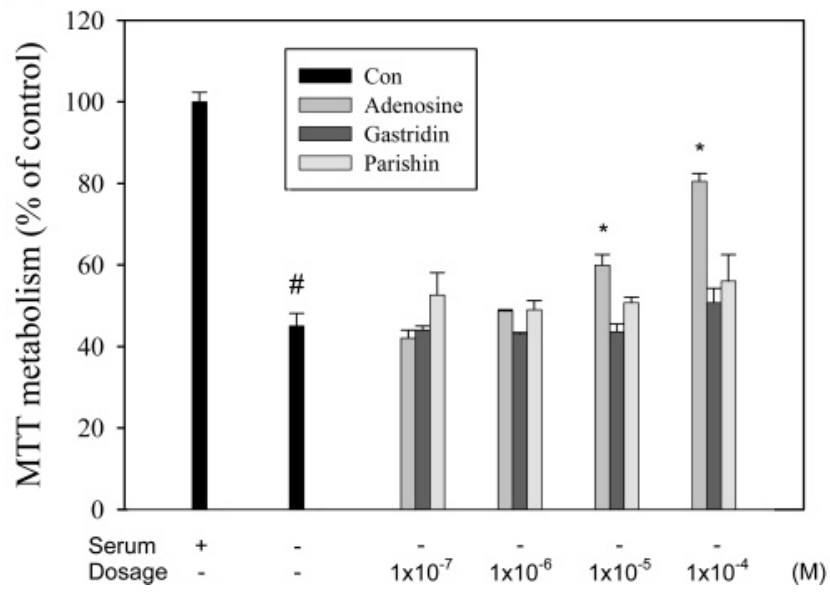

Figure 1. Prevention of serum deprivation-induced PC12 cell apoptosis by (A) compounds $\mathbf{1}$ and $\mathbf{2}$ and (B) adenosine, gastrodin, and parishin from $G$. elata. Serum-deprived PC12 cells were treated with or without the indicated drug at the desired concentration for $24 \mathrm{~h}$. Cell viability was monitored by the MTT assay and is expressed as a percentage of the MTT activity measured in the serum-containing group. Data points represent the mean \pm SEM of at least three independent experiments $(n=3-6)$. (\#: $p<0.05$, serum-deprived group compared with control; *: $p<0.05$, compounds 1- and 2-treated groups compared with serum-deprived group). 
about a $15 \%$ yield based on the dried rhizome weight) was subjected to Diaion HP-20 column chromatography with elution using a gradient from $\mathrm{H}_{2} \mathrm{O}$ to $\mathrm{MeOH}$. The active fractions of $50 \%-75 \% \mathrm{MeOH} / \mathrm{H}_{2} \mathrm{O}$ were repeatedly purified by passage over a Sephadex LH-20 column and elution with $\mathrm{MeOH}$ or $80 \% \mathrm{MeOH}$ to yield 1 (1.85 g), 2 (167 $\mathrm{mg}$ ), 4-hydroxybenzaldehyde (78 mg), 4-hydroxybenzyl alcohol (315 $\mathrm{mg})$, 4-hydroxybenzyl methyl ether ( $85 \mathrm{mg})$, 4-hydroxybenzyl ethyl ether $(93 \mathrm{mg}), 1,4$-benzenediol $(63 \mathrm{mg})$, gastrodin $(25 \mathrm{~g}), 4-(\beta$-Dglucopyranosyloxy)benzyl methyl ether $(35 \mathrm{mg})$, parishin $(55 \mathrm{~g})$, bis(4-hydroxybenzyl) ether $(48 \mathrm{mg})$, trimethyl citrate $(3.6 \mathrm{~g})$, bis(4hydroxybenzyl) sulfoxide (36 mg), bis(4-hydroxybenzyl) (45 mg), 5-(hydroxymethyl)-2-furfuraldehydealdehyde (26 mg), uridine (32 mg), and adenosine $(43 \mathrm{mg})$.

Compound 1: pale yellow needles from EtOH; mp 136-138 ${ }^{\circ} \mathrm{C}$; IR $(\mathrm{KBr}) v_{\max } 3285(\mathrm{OH}), 1604,1600,1509(\mathrm{C}=\mathrm{C}), 1214,1089(\mathrm{OH})$ $\mathrm{cm}^{-1}$; EIMS m/z (\%) $246\left(\mathrm{M}^{+}, 35\right), 200$ (15), $107(100) ;{ }^{1} \mathrm{H}$ and ${ }^{13} \mathrm{C}$ NMR data are in good agreement with the published data. ${ }^{22}$

Compound 2: colorless needles from EtOH; $\mathrm{mp} 216-219{ }^{\circ} \mathrm{C} ;[\alpha]^{25} \mathrm{D}$ -87 ( c 0.1, MeOH); IR (KBr) $v_{\max } 3327,3164,2927,1630,1514$, $1125,1057,815 \mathrm{~cm}^{-1} ;{ }^{1} \mathrm{H}$ NMR (DMSO- $\left.d_{6}, 500 \mathrm{MHz}\right) \delta 3.57$ and $3.64\left(1 \mathrm{H}\right.$ each, m, H-5'), $3.95\left(1 \mathrm{H}, \mathrm{t}, J=1.8 \mathrm{~Hz}, \mathrm{H}-4^{\prime}\right), 4.13(1 \mathrm{H}, \mathrm{m}$, H-3'), 4.60 (3H, m, H-2', H-7'), 5.88 (1H, d, $\left.\left.J=6.5 \mathrm{~Hz}, \mathrm{H}-1^{\prime}\right)\right), 6.66$ and 7.14 (2H each, d, $\left.J=8.5 \mathrm{~Hz}, \mathrm{H}-3^{\prime \prime}\left(5^{\prime \prime}\right), \mathrm{H}-2^{\prime \prime}\left(6^{\prime \prime}\right)\right), 8.20$ and 8.35 (1H each, s, H-8 and $\mathrm{H}-2), 8.28$ and $9.19(1 \mathrm{H}$ each, br s, NH, OH); ${ }^{13} \mathrm{C}$ NMR (DMSO- $\left.d_{6}, 125 \mathrm{MHz}\right) \delta 42.4$ (t, C-7"), 61.7 (t, C-5'), 70.7 (d, C-3') 73.5 (d, C-2'), 85.9 (d, C-4'), 88.0(d, C-1'), 114.9 (d, C-3"(5")), 120.4 (s, C-5), 128.6 (d, C-2"(6")), 130.8 (s, C-1"), 139.8 (d, C-8), 148.4 (s, C-4), 152.3 (d, C-2), 154.5 (s, C-6), and 156.1 (s, C-4"); HMBC correlations H-2/C-4, C-6; H-8/C-4, C-5; H-7"/C-6, C-1", C-2"(6"); FABMS m/z (\%) $374\left[(\mathrm{M}+\mathrm{H})^{+}, 28\right], 242$ (15), 154 (95), 136 (83), 56 (100); HRFABMS m/z 374.1361 (calcd for $\mathrm{C}_{17} \mathrm{H}_{20} \mathrm{O}_{5} \mathrm{~N}_{5}$, 374.1388).

Synthesis of Compound 2. Hydroxylamine hydrochloride (1.29 g, $18.6 \mathrm{mmol})$ and $\mathrm{NaOAc}(1.67 \mathrm{~g}, 20.4 \mathrm{mmol})$ were added to a solution of 4-hydroxybenzaldehyde $(1.25 \mathrm{~g}, 10.2 \mathrm{mmol})$ in $\mathrm{EtOH}(20 \mathrm{~mL})$. The reaction mixture was stirred at room temperature for $6 \mathrm{~h}$. EtOH was removed under reduced pressure. $\mathrm{H}_{2} \mathrm{O}$ was added to the residue and then extracted with $\mathrm{Et}_{2} \mathrm{O}(3 \times)$. The combined organic layer was dried over $\mathrm{MgSO}_{4}$. After the volatiles were removed by rotary evaporation under reduced pressure, the residue was recrystallized from $\mathrm{CH}_{2} \mathrm{Cl}_{2}$ to give oxime $3(1.3 \mathrm{~g}, 93 \%):{ }^{30,31} \mathrm{C}_{7} \mathrm{H}_{7} \mathrm{NO}_{2}$; light yellow solid; $\mathrm{mp} 92.0-$ 93.6 ${ }^{\circ} \mathrm{C}$; ESIMS $\mathrm{m} / \mathrm{z}, 138.0620\left(\mathrm{M}^{+}+\mathrm{H}\right)$ (calcd for $\mathrm{C}_{7} \mathrm{H}_{8} \mathrm{NO}_{2}$, 138.0600).

A solution of $\mathbf{3}(342 \mathrm{mg}, 2.5 \mathrm{mmol})$ and concentrated $\mathrm{HCl}(1 \mathrm{~mL})$ in EtOH $(20 \mathrm{~mL})$ was subjected to hydrogenation at atmospheric pressure in the presence of $10 \% \mathrm{Pd} / \mathrm{C}(80 \mathrm{mg})$ for $4.5 \mathrm{~h}$. The reaction mixture was filtered through Celite. The filtrate was concentrated to yield the hydrochloric salt of amine $\mathbf{4}$ as a light yellow solid, which was used for the next step without further purification. ${ }^{31,32}$

A mixture of amine 4 (395 mg, as the hydrochloric salt), 6-chloropurine ribonucleoside $(\mathbf{5})(143 \mathrm{mg}, 0.5 \mathrm{mmol})$, and diisopropylethylamine $(2 \mathrm{~mL}, 12 \mathrm{mmol})$ in $\mathrm{PrOH}(25 \mathrm{~mL})$ was heated to $70{ }^{\circ} \mathrm{C}$ for 6 h. After evaporation, the mixture was triturated with $\mathrm{H}_{2} \mathrm{O}$ to give a white precipitate, which was filtered to yield the desired product 2 (151 $\mathrm{mg}, 81 \%){ }^{32,33}$ The physical data (including the $\mathrm{mp}$, MS, $R_{f}$ value of TLC, ${ }^{1} \mathrm{H}$ and ${ }^{13} \mathrm{C}$ NMR) of the synthesized product were in good agreement with compound $\mathbf{2}$ isolated from the rhizomes of $G$. elata.

Cell Culture. PC12 cells purchased from ATCC (Manassas, VA) were maintained in DMEM supplemented with $10 \%$ horse serum and $5 \%$ fetal bovine serum and incubated in a $\mathrm{CO}_{2}$ incubator $(5 \%)$ at 37 ${ }^{\circ} \mathrm{C}$.

MTT Assay. PC12 cells were serum-deprived by three washes of PBS and resuspended in DMEM. The suspended cells were plated on 96-well plates $\left(1 \times 10^{4}\right.$ cells/well $)$ and treated with the indicated reagent(s). After treatment for $21 \mathrm{~h}, 3$-(4,5-dimethylthiazol-2-yl)-2,5diphenyl tetrazolium bromide (MTT) was added to the medium (0.5 $\mathrm{mg} / \mathrm{mL}$ ), and the mixture was incubated at $37^{\circ} \mathrm{C}$ for another $3 \mathrm{~h}$. After discarding the medium, $100 \mu \mathrm{L}$ of DMSO was then applied to the well to dissolve the formazan crystals, and the absorbances at 570 and 630 $\mathrm{nm}$ in each well were measured on a micro-ELISA reader.

$\mathbf{A}_{2 \mathrm{~A}}$ Receptor Binding Assay. Membranes were thawed and preincubated for $60 \mathrm{~min}$ at $3{ }^{\circ} \mathrm{C}$ at a protein concentration of $0.8 \mu \mathrm{g} /$ $\mathrm{mL}$ in binding buffer with adenosine deaminase $(2 \mathrm{U} / \mathrm{mL})$. In one set of experiments we also incubated the membranes without adenosine deaminase for $\left[{ }^{3} \mathrm{H}\right] \mathrm{DPCPX}$ binding. A 96 -well microplate filtration system (Millipore MultiScreen MAFB) was used for the binding experiments. Before use, the filters in the plates were presoaked in 20 $\mu \mathrm{L}$ of binding buffer. For the saturation binding experiments, increasing concentrations of the radioligands for the $\mathrm{A}_{2 \mathrm{~A}}-\mathrm{R}\left(\left[{ }^{3} \mathrm{H}\right] \mathrm{SCH}\right.$ 58261) were incubated with the membrane protein in a final volume of $300 \mu \mathrm{L}$ in binding buffer. The incubation mixture contained $22.5 \mu \mathrm{g}$ of protein for $\left[{ }^{3} \mathrm{H}\right] \mathrm{DPCPX}$ binding and $60 \mu \mathrm{g}$ of protein for $\left[{ }^{3} \mathrm{H}\right] \mathrm{SCH} 58261$ binding. GTP at a final concentration of $500 \mu \mathrm{M}$ was used where indicated. Nonspecific binding was defined as the binding in the presence of $500 \mu \mathrm{M}$ 2-chloroadenosine. Samples were incubated at room temperature for either $2 \mathrm{~h}$ for $\left[{ }^{3} \mathrm{H}\right] \mathrm{DPCPX}$ binding or $1 \mathrm{~h}$ for $\left[{ }^{3} \mathrm{H}\right] \mathrm{SCH} 58261$ binding, filtered through the built-in filter at the bottom of the wells, and washed three times with $300 \mu \mathrm{L}$ of ice-cold binding buffer. After addition of $30 \mu \mathrm{L}$ of scintillation fluid to the dried filter, the plates were incubated overnight at room temperature and counted. $\mathrm{IC}_{50}$ values were determined by a nonlinear, least-squares regression analysis using Data Analysis Toolbox (MDL Information System, San Leandro, CA). ${ }^{34}$ The inhibition constants $\left(K_{\mathrm{i}}\right)$ were calculated using the equation of Cheng and Prusoff. ${ }^{35}$

Acknowledgment. We are grateful to the National Science Council, Republic of China, for support of this research under grant NSC 952323-B-077-002.

\section{References and Notes}

(1) Batistatou, A.; Greene, L. A. J. Cell. Biol. 1991, 115, 461-471.

(2) Rukenstein, A.; Rydel, R. E.; Greene, L. A. J. Neurosci. 1991, 11, 2552-2563.

(3) Glass, M.; Dragunow, M.; Faull, R. L. Neuroscience 2000, 97, 50519.

(4) Gardian, G.; Vecsei, L. J. Neural Transm. 2004, 111, 14851494.

(5) Weaver, D. R. Brain Res. Mol. Brain Res. 1993, 20, 313-27.

(6) Lee, Y. C.; Chien, C. L.; Sun, C. N.; Huang, C. L.; Huang, N. K.; Chiang, M. C.; Lai, H. L.; Lin, Y. S.; Chou, S. Y.; Wang, C. K. L.; Tai, M. H.; Liao, W. L.;Lin, T. N.; Liu, F. C.; Chern, Y. Eur. J. Neurosci. 2003, 18, 1786-1796.

(7) Chou, S. Y.; Lee, Y. C.; Chen, H. M.; Chiang, M. C.; Lai, H. L.; Chang, H. H.; Wu, Y. C.; Sun, C. N.; Chieh, C. L.; Lin, Y. S.; Wang, S. C.; Tung, Y. Y.; Chang, C.; Chern. Y. J. Neurochem. 2005, 93, 310-320.

(8) Hus, H. Y.; Chen, Y. P.; Hsu, S. J.; Hsu, C. S.; Chen, C. C.; Chang, H. C. Oriental Materia Medica: A Concise Guide; Oriental Health Art Institute: California, 1986; p 662.

(9) An, S. J.; Park, S. K.; Hwang, I. K.; Choi, S. Y.; Kim, S. K.; Kwon, O. S.; Jung, S. J.; Baek, N. I.; Lee, H. Y.; Won, M. H.; Kang, T. C. J. Neurosci. Res. 2003, 71, 534-543.

(10) Kim, H. J.; Moon, K. D.; Oh, S. Y.; Kim, S. P.; Lee, S. R. Neurosci. Lett. 2001, 314, 65-68.

(11) Kim, H. J.; Lee, S. R.; Moon, K. D. Phytother. Res. 2003, 17, 909912.

(12) Kim, H. J.; Moon, K. D.; Lee, D. S.; Lee, S. H. J. Ethnopharmacol. 2003, 84, 95-98.

(13) Hsieh, C. L.; Chiang, S. Y.; Cheng, K. S.; Lin, Y. H.; Tang, N. Y.; Lee, C. J.; Pon, C. Z.; Hsieh, C. T. Am. J. Chin. Med. 2001, 29, $331-341$.

(14) Hsieh, C. L.; Chang, C. H.; Chiang, S. Y.; Li, T. C.; Tang, N. Y.; Pon, C. Z.; Hsieh, C. T.; Lin, J. G. Life Sci. 2000, 67, 11851195.

(15) Huang, N. K.; Lin, Y. L.; Cheng, J. J.; Lai, W. L. Life Sci. 2004, 75, $1649-1657$

(16) Taguchi, H.; Yoshioka, I.; Yamasak, K.; Kim, I. H. Chem. Pharm. Bull. 1981, 29, 55-62.

(17) Noda, N.; Kobayashi, Y.; Miyahara, K.; Fukahori, S. Phytochemistry 1995, 39, 1247-1248.

(18) Lin, J. H.; Liu, Y. C.; Hau, J. P.; Wen, K. C. Phytochemistry 1996 42, 549-551.

(19) Hayashi, J.; Sekine, T.; Deguchi, S.; Lin, Q.; Horie, S.; Tsuchiya, S.; Yano, S.; Watanabe, K.; Ikegami, F. Phytochemistry 2002, 59, 513-519.

(20) Yun-Choi, H. S.; Pyo, M. K.; Park, K. M. Arch. Pharm. Res. 1997, 20, 91-92

(21) Huang, Z. B.; Song, D. M.; Chen, F. K. Chin. J. Med. Chem. 2005, $15,227-229$.

(22) Xiao, Y. Q.; Li, L.; You, X. L. China J. Chin. Materia Med. 2002, 27, 35-36.

(23) Wang, L.; Xiao, H. B.; Liang, X. M. Chin. Trad. Herbal Drugs 2003, $34,584-585$.

(24) Coll, J.; Bowden, B. J. Nat. Prod. 1986, 49, 934-936.

(25) Sagner, S.; Kneer, R.; Wanner, G.; Cosson, J. P.; Deus-Neumann, B.; Zenk, M. H. Phytochemistry 1998, 47, 339-347. 
(26) Shimizu, M.; Zenko, Y.; Tanaka, R.; Matsuzawa, T.; Morita, N. Chem. Pharm. Bull. 1993, 41, 1469-1471.

(27) Lin, Y. L.; Wang, W. Y.; Kuo, Y. H.; Chen, C. F. J. Chin. Chem. Soc. 2000, 47, 247-251.

(28) Strnad, M.; Hanus, J.; Vanek, T.; Kaminek, M.; Ballantine, J. A.; Fussell, B.; Hanke, D. E. Phytochemistry 1997, 45, 213-218.

(29) Thompson, R. D.; Secunda, S.; Daly, J. W.; Olsson, R. A. J. Med. Chem. 1991, 34, 3388-3390.

(30) Koyama, H.; Boueres, J. K.; Han, W.; Metzger, E. J.; Bergman, J. P.; Gratale, D. F.; Miller, D. J.; Tolman, R. L.; MacNaul, K. L.; Berger, J. P.; Doebber, T. W.; Leung, K.; Moller, D. E.; Hecka, J. V.; Sahooa, S. P. Bioorg. Med. Chem. Lett. 2003, 13, 1795-1799.

(31) Gannett, P. M.; Nagel, D. L.; Reilly, P. J.; Lawson, T.; Sharpe, J.; Toth, B. J. Org. Chem. 1988, 53, 1064-1071.
(32) Trivedi, B. K.; Blankley, C. J.; Bristol, J. A.; Hamilton, H. W.; Patt, W. C.; Kramer, W. J.; Johnson, S. A.; Bruns, R. F.; Cohen, D. M.; Ryan, M. J. J. Med. Chem. 1991, 34, 1043-1049.

(33) Golisade, A.; Wiesner, J.; Herforth, C.; Jomaab, H.; Linka, A. Bioorg. Med. Chem. 2002, 10, 769-777.

(34) Uhlen, S.; Dambrova, M.; Nasman, J.; Schioth, H. B.; Gu, Y. Wikberg-Matsson, A.; Wikberg, J. E. Eur. J. Pharmacol. 1998, 343, 93-101.

(35) Cheng, Y.; Prusoff, W. H. Biochem. Pharmacol. 1973, 22, 30993108

NP0605182 